\title{
2ストロークエアアシスト式直噴船奴㤦の開発 \\ Development of Two-Stroke Air Assisted Direct Fuel Injection Outboard Motor \\ 来元潤-・(トーハツ)
}

Junichi Inomoto, Tohatsu Corporation 3-4-9, Azusawa I tabashi-ku, Tokyo

\section{1.まえがき}

北米市場において船外㙨を対象とした、排気ガス規制(以 下「EPA 規制」)が 1998 年から実施されており、段階的に規 制值を強化し 2006 年に最終段階に至る。最終規制值は従来 型䑪外機の平均的な排父ガス排出量に対して約 $75 \%$ 削減 という非常に厳しいものとなっている。

\section{2 . 開発の背景}

船外機用エンジンとして、キャブレタ式 2 ストロークエ ンジンが多く用いられてきたが、排気ガス性能が少るため。 EPA 想制によって制限を受けることになる。2 ストローク で問題となるのは未燃爟ガス成分である HC の排出で、般に次の現象が原因とされている。

(1)、掃気行程における新気の吹き报け

(2)、低負荷領域での失火による未燃㟋ガスの排川

当時、国内外において㨁噴式 2 ストロークの研究(1)(2)(3)が 盛んに行われており、これらによれば掃気行程を空気だけ で行い，排気ポートを閉じてから燃料を燃焼室に噴射する ことで根本的に吹き报けを防止できる。また、層状燃焼させ ることで失火を防止できることから、HC 排出量を大幅に 低減することが可能である。

当社は、晅嗿システムの扸究開発を行っているオースト ラリアのオービタル社と技術提携し、既存の $50 \mathrm{HP}$ 船外機 をべースにエアアシスト式 2 ストローク晅噴船外機の開発 を行ったので、システムの概要と排気ガス低減効果につい て以トに報告する。Table.1 は当開発のベースエンジンの緒 元である。

Table 1 : Base Engine specifications.

\begin{tabular}{|l|l|}
\hline Engine Type & 2stroke-3cylinder \\
\hline Fuel & Gasoline \\
\hline Displacement & $697 \mathrm{ml}$ \\
\hline Bore $\times$ Stroke & $68 \mathrm{~mm} \times 64 \mathrm{~mm}$ \\
\hline Max. Power & $36.8 \mathrm{~kW} / 5500 \mathrm{r} / \mathrm{m}$ \\
\hline
\end{tabular}

閏発に着手するにあたって以下の目䌘を揭げた。

(1)，EPA2000 作晛制を余裕を持ってクリアすること

(2)，䑧外機としての倩品性を損なわないこと

（3）、新技術導人によるユーザーメリットを引き忺すこと

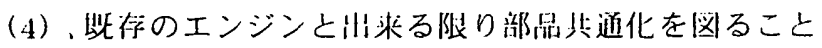

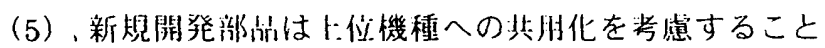

\section{3.エアアシスト式噴射装置}

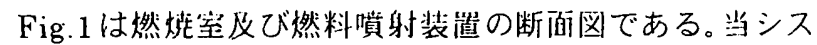
テムでは1父筒につきフュエルインジエクタとエアインジ エクタの 2 侗のインジェクタを优用する。备インジェクタ はフュエル・エアレールと眯ばれるコモンレールを介して シリンダヘッドに彼り付けられている。

フュエルインジェクタの燃料人に部は，630kPaに玔!

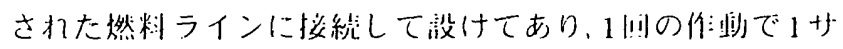

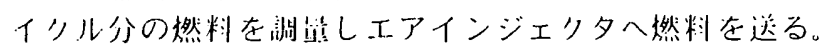

エアインジェクタの人い侧は、耖ほ上゙の然籼が人る近路 上 $550 \mathrm{kPa}$ の川:維皆父ラインにつながる近路を狩ち、畹射
ノズルが開くと、压縮空気によってエアインジェクタ内の 燃料が燃焼公に噴射される。

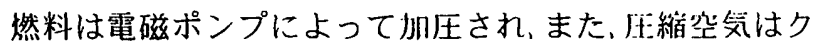
ランクシャフトからベルト駆動されるコンプレッサによっ て加圧・供給されており、それぞれレギュレータによって光 述の压力となるように制御されている。

コモンレールには㜣料ライン, 㞔綰空気ラインの他、ベー パーロックを防止するために冷却水ラインを設けている。

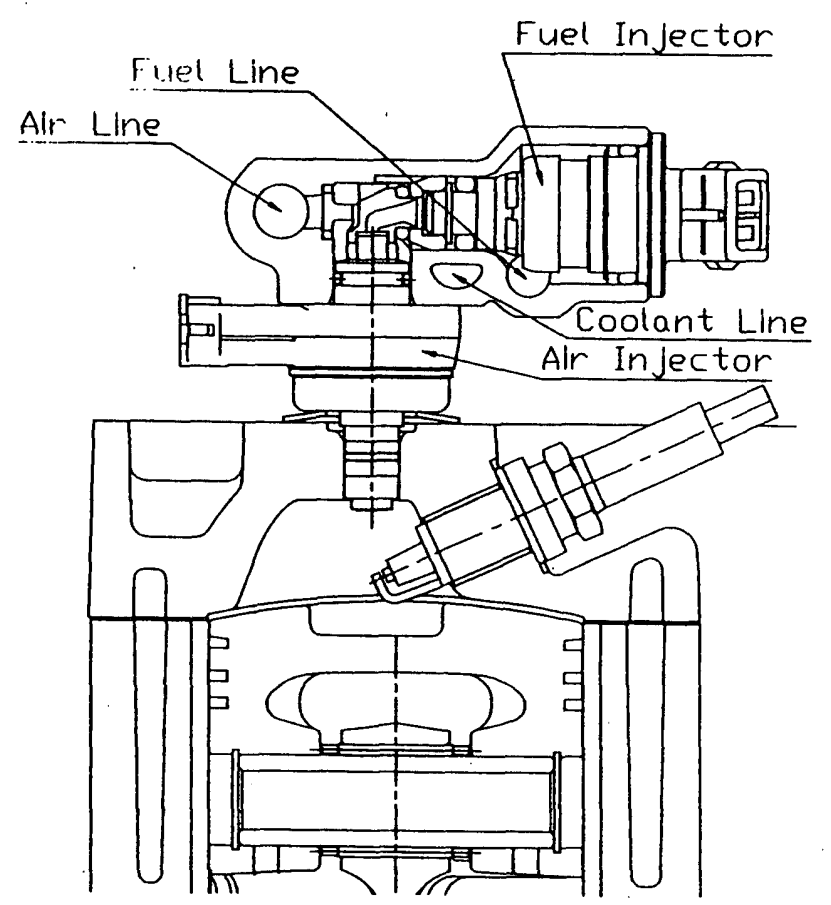

Fig.1 : Injection System and Combustion Chamber.

燃焼室は深いドーム状で排気ポートの逆側にオフセット

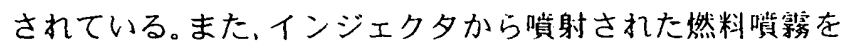
ドーム方向へ反転させる為ビストンクラウンにめ $27 \times$ 深 サ約 $5 \mathrm{~mm}$ のキャビティが設けられて拉り、ドームと间汃 㓩にオフセットされている。エアインジェク夕の貲影ノズ ルはドーム侧からピストンキャビティに対し垭任に貲射す

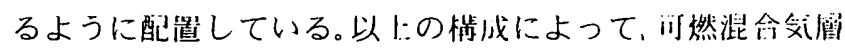
はドームの川部に丯成される。これに着火させるため，ス パークブラグの発火部はかなり榮き出さ扎ている。以、に よって低負街領域での屏状燃绉を可能としているが、笑際 の可燃混合気層は掃気流によって乱さ打るため，エアイン

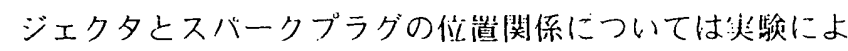
って最適位䍀を炏苳している。

\section{4. 燃焼方式}

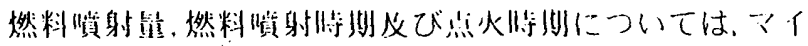
クロコンビュータによる倠お例御を行ーてている。

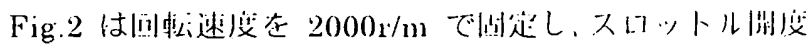

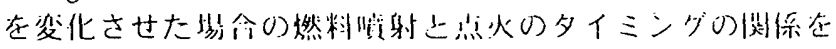

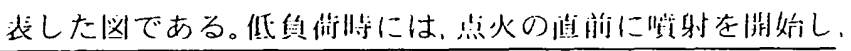

日本機械学会 [No.017-1] 北陸信越支部 第 38 期総会・講演会論文集 ['01.3.15,上田市] 
噴霧がスパークプラグにかかったところで点火することに よる層状燃焼とし、高負荷時には出力確保のため噴射封期 を進角させる均一混合燃焼としている。

Fig.3はアイドリング時の燃娔圧波形である。図のように、 失火サイクルはほぼ完全になくなっており、回転変動の少 ないスムーズな、アイドリングを奏現している。

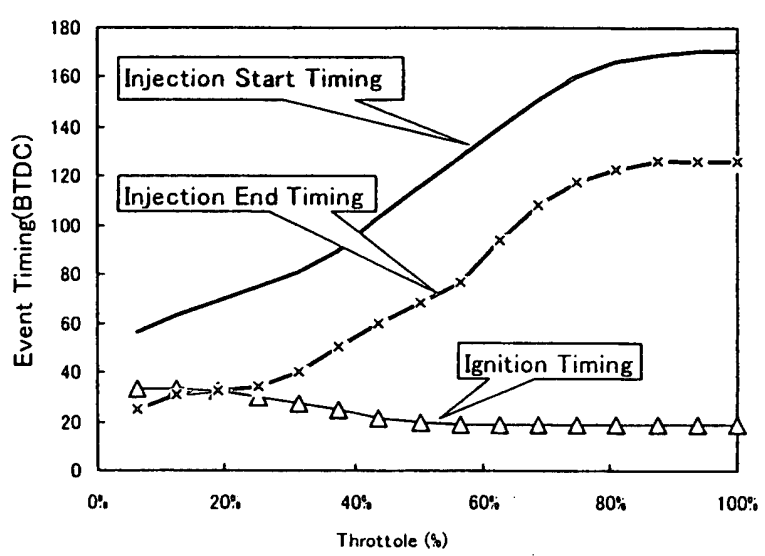

Fig. 2 : Section of Timing Surface at $2000 \mathrm{r} / \mathrm{m}$

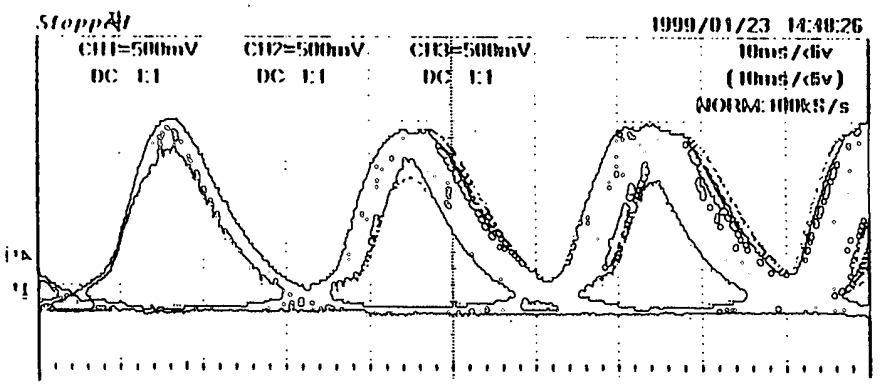

Fig. 3 : Combustion Pressure at Idle $(700 \mathrm{r} / \mathrm{m})$

\section{4. 排気ガス性能}

Fig.4 はキャブレタ式とエアアシスト式值噴との、 ICOMIA モードによる排気ガス排出量の比較である。図の 通り、EPA で規制される $\mathrm{HC}+\mathrm{NOx}$ 排仙量は、キャブレタ式 に刘して 75\%低減され、EPA2006作規制に対しては $20 \%$ の 余裕を持ってクリアしている。

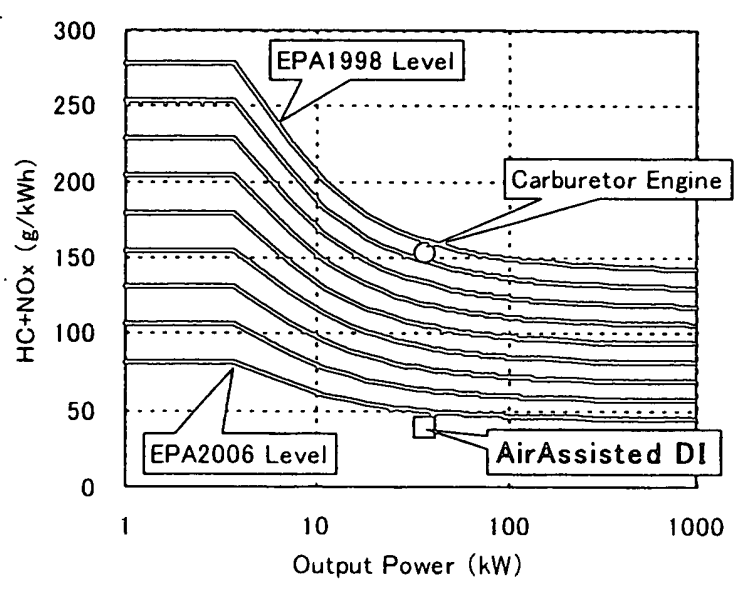

Fig. 4: Emission Level of Air Assisted DI And Carburetor Engine

こ打に伴って㜣出も收源され、キャブレタ式に刘して㜣

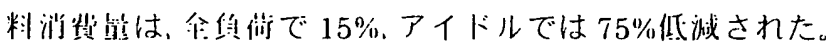

\section{5. 出力阵能}

㨁噴化したエンジンにおいて出力性能を維持する上で、 次のネガティブな要素が明らかになった。

一エアコンプレッサの駆動ロス

一クランクケースの燃料冷却がなくなり吸気温度が_L: 昇したことによる吸入効率の低下

しかし、次のポジティブな要素も確認された。

一燃料噴射によってスパークプラグが命却されるため 耐ノック性が向上しており、压縮比を高く設定する ことができた。

一然料の吹き报けがなくなることから、排気管を最大 出力本意で設計することができた。

以上のトレードオフをバランスさせ、最大出力は従来機 種と同じ $50 \mathrm{HP} / 5500 \mathrm{rpm}$ を確保することができた。

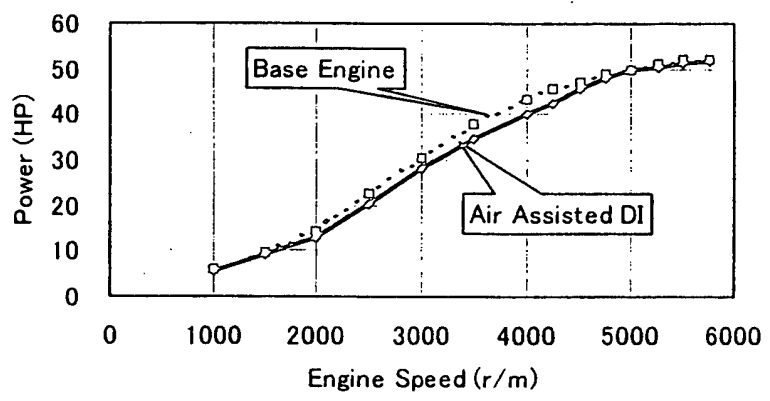

Fig.5 : WOT Power

\section{6. 結界}

本開発の目標に対し、以下の結果を得た。

(1)、EPA2006 年規制に対して $20 \%$ の余裕を持って寏合す ることができた。

(2)、ベースエンジンと同じ最大山少確保し、失火を解消 したことによってスムーズな運転特性を得ることができた。 （3）、燃䩀の大幅低減、始動操作の容易化、不整燃筧による 不快な振動の低減など、実用的なメリットが得られた。

(4)、エアコンプレッサや燃料ボンブなどの新規開発激品は、 大型機種への共用化を考虑しながら、ベースエンジンとほ ぼ同等のパッケージに収めることができた。

\section{7.おわりに}

当開発で2ストロークエンジンに対する值噴システムの 導入に成功し、排気ガスを大幅に低減することができた。今 後さらにシステムを熟成させ、性能何上と排気ガス低減を 進めるとともに、他機種への直唄技術導人を履開し、啨境対 策に員献したいと考えている。

\section{参考文瑚}

(1) D Worth , N Coplin, M Mcniff, M Stannard, "DESIGN CONSIDERATIONS FOR THE APPLICATION OF AIR ASSISTED DIRECT IN-CYLINDER INJECTION SYSTEMS", SETC'97 Proceedings, SAE Paper 972074.

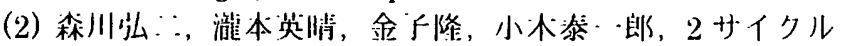

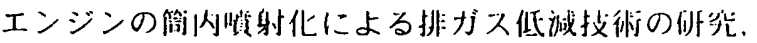
LEMA No.459(2000)

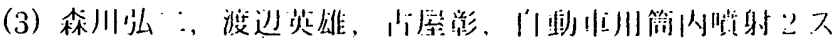

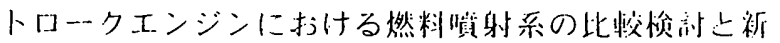

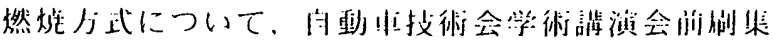
$953(1995 \cdot 5)$. 